\title{
DIFFERENTIAL BINDING OF TRITIATED ACTINOMYCIN TO THE NUCLEI OF MAMMALIAN SPERMATOGENIC CELLS IN VIVO
}

\author{
W. J. BARCELLONA,* R. B. BRAGKEEN AND B. R. BRINKLEY \\ Division of Cell Biology, Department of Human Biological Chemistry and Genetics, \\ The University of Texas Medical Branch, Galveston, Texas 77550, U.S.A.
}

(Received 24th September 1973)

Summary. Chinese hamsters, Cricetulus griseus, were given a single injection of $2.0 \mu \mathrm{g}\left[{ }^{3} \mathrm{H}\right]$ actinomycin $\mathrm{D}$ directly into the left testis. For $24 \mathrm{hr}$ after injection, the distribution of the radioisotope in the reproductive organs, blood plasma and liver was followed, using liquid scintillation counting techniques. After $24 \mathrm{hr}$, nearly $50 \%$ of the injected dose remained in the left testis while insignificant amounts of label were associated with the right testis. The left epididymis gradually accumulated radioisotope probably by intratubular transport from the left testis. The right epididymis possessed negligible amounts of label after $24 \mathrm{hr}$. Levels of the antibiotic in blood plasma and liver steadily decreased during the experimental period.

Localization of $\left[{ }^{3} \mathrm{H}\right]$ actinomycin $\mathrm{D}$ within the spermatogenic cells of the seminiferous epithelium was determined by autoradiography. The results indicated that the antibiotic was differentially bound by various types of spermatogenic cells. Of the spermatocytes, Stage VIII leptotene nuclei (31.6 grains/nucleus) were much more heavily labelled compared to early Stage $\mathrm{V}$ pachytene nuclei ( $6 \cdot 2$ grains/nucleus). Actinomycin $\mathrm{D}$ was lightly bound to nuclei of Step 5 and Step 8 round spermatids (3.6 and 3.8 grains/nucleus, respectively). Elongating spermatid nuclei (Steps 9 to 14) were lightly labelled at best, whereas elongated spermatid nuclei (Steps 15 to 18 ) were very heavily grained. The label intensity decreased in Step-19 spermatids (spermiation step). Labelling variations among spermatogenic cells may be attributable to the physicochemical state of deoxyribonucleoprotein complexes in these cells.

\section{INTRODUCTION}

Synthesis of RNA during meiotic prophase I of spermatogenesis in rodent species has been demonstrated by autoradiography (Monesi, 1964, 1965; Utakoji, 1966), but the exact function of this RNA is not yet known. The

* Present address: Department of Biology, Texas Christian University, Fort Worth, Texas 76129, U.S.A. 
possibility that it may be required in germ cell differentiation led us to study the effects of actinomycin D (AMD) in vivo on RNA synthesis, histology and the ultrastructure of the seminiferous epithelium from Chinese hamsters (Barcellona \& Brinkley, 1973).

There have been reports in the literature concerning the binding of $\left[{ }^{3} \mathrm{H}\right] \mathrm{AMD}$ to mouse (Brachet \& Hulin, 1969), bull (Darżynkiewicz, Gledhill \& Ringertz, 1969; Loir \& Hochereau-de Reviers, 1972) and ram (Loir \& Hochereau-de Reviers, 1972) spermatogenic cells using quantitative autoradiography. Mouse and ram cells were exposed to labelled antibiotic after fixation, and cells from the bull were cultured with $\left[{ }^{3} \mathrm{H}\right] \mathrm{AMD}$ in vitro before fixation. In all cases, the authors showed differential binding of $\left[{ }^{3} \mathrm{H}\right] \mathrm{AMD}$ to various types of spermatogenic cells.

In this paper we report the localization in vivo of $\left[{ }^{3} \mathrm{H}\right] \mathrm{AMD}$ in the seminiferous epithelium of Chinese hamsters, and the distribution of the labelled antibiotic in different body compartments under the conditions of our previous studies.

\section{MATERIALS AND METHODS}

Tritiated AMD was obtained from Schwarz/Mann, Orangeburg, N.Y. (original sp. act., $6.5 \mathrm{Ci} / \mathrm{mmol}$ ) and was adjusted to a sp. act. of $5.8 \mathrm{mCi} / \mathrm{mmol}$ with unlabelled AMD (Calbiochem, Los Angeles, Calif.). Sexually mature male Chinese hamsters, Cricetulus griseus, weighing 35 to $40 \mathrm{~g}$ were used throughout this study. Hamsters were anaesthetized with ether for all intratesticular injections. Left testes were directly injected with $9.4 \mu \mathrm{Ci}\left[{ }^{3} \mathrm{H}\right] \mathrm{AMD}$ in $0.1 \mathrm{ml}$ Hanks' salt solution (HSS). A total of $2.0 \mu \mathrm{g}$ AMD was injected into each animal. Right testes received $0 \cdot 1 \mathrm{ml}$ HSS. Animals were killed at 1, 4, 8 and $24 \mathrm{hr}$ after injection of the radioisotope.

Blood samples were obtained by cardiac puncture and were centrifuged. Blood plasma was isolated and diluted 1:4 with Sörensen's phosphate buffer at $\mathrm{pH} \mathrm{7.4}$. Liver, left and right testes, and left and right epididymides were removed, weighed and homogenized in phosphate buffer. The homogenates consisted of 1 part tissue: 4 parts buffer, $w / v$. Duplicate plasma and homogenate samples $(0.3 \mathrm{ml}$ ) were incubated in $2.0 \mathrm{ml}$ Protosol (New England Nuclear, Boston, Mass.) at $55^{\circ} \mathrm{C}$ for $3 \mathrm{hr}$. After tissue solubilization in Protosol, $15.0 \mathrm{ml}$ of Aquasol (New England Nuclear) and $0.2 \mathrm{ml}$ glacial acetic acid were added to all samples. Acetic acid was used to eliminate chemiluminescence. Samples were counted on a Packard Model 3002 Tri-Carb Liquid Scintillation Spectrometer which had a counting efficiency of $32 \%$ at $4^{\circ} \mathrm{C}$. Phosphate buffer was used in the blank to determine the background of the liquid scintillation counter. Liver samples were corrected for colour quenching with an internal ${ }^{3} \mathrm{H}$ standard.

For autoradiographic experiments, animals were injected at the approximate centre of a testis with either AMD or HSS as previously described. Animals were killed $24 \mathrm{hr}$ after the injection of the radioisotope. Testes were fixed in Bouin's fluid, embedded in paraplast, and sectioned at $5 \mu \mathrm{m}$. Histological sections were cleared, stripped with Kodak A.R. 10 stripping film and exposed dry 
for 3 months at $4^{\circ} \mathrm{C}$. Autoradiographs were developed with D19b, and stained with haematoxylin and eosin (Baserga \& Malamud, 1969).

\section{RESULTS}

Table 1 shows the distribution of $\left[{ }^{3} \mathrm{H}\right] \mathrm{AMD}$ in some body compartments of the Chinese hamster after intratesticular injection. The results indicate that the $\left[{ }^{3} \mathrm{H}\right]$ AMD content of the left testis decreased for up to $24 \mathrm{hr}$. At this time, a significant portion of the injected label (approximately 50\%) still remained localized at the site of injection. Only insignificant amounts of $\left[{ }^{3} \mathrm{H}\right] \mathrm{AMD}$ were present in the right testis during the entire period of exposure to the radioisotope. Label gradually accumulated in the left epididymis with time, but only negligible amounts of label could be found in the right epididymis after

Table 1. Radioisotope content of various body compartments of Chinese hamsters following intratesticular injection with $\left[{ }^{3} \mathrm{H}\right]$ actinomycin D

\begin{tabular}{c|c|c|c|c|c|c|c}
\hline $\begin{array}{c}\text { Time after } \\
{\left[\begin{array}{c}\left.{ }^{3} \mathrm{H}\right] \text { AMMD } \\
\text { injection } \\
(\text { hr })\end{array}\right.}\end{array}$ & $\begin{array}{c}\text { No. of } \\
\text { animals }\end{array}$ & $\begin{array}{c}\text { Blood } \\
\text { plasma* }\end{array}$ & Liver $\dagger$ & $\begin{array}{c}\text { Left } \\
\text { testis } \dagger\end{array}$ & $\begin{array}{c}\text { Right } \\
\text { testis } \dagger\end{array}$ & $\begin{array}{c}\text { Left } \\
\text { epididymis } \dagger\end{array}$ & $\begin{array}{c}\text { Right } \\
\text { epididymis } \dagger\end{array}$ \\
\hline 1 & 4 & $4562 \pm 195$ & $24 \cdot 1 \pm 1 \cdot 3$ & $636 \cdot 0 \pm 31 \cdot 8$ & $1 \cdot 8 \pm 0 \cdot 1$ & $3 \cdot 6 \pm 0 \cdot 4$ & $2 \cdot 1 \pm 0 \cdot 1$ \\
4 & 4 & $2523 \pm 186$ & $15 \cdot 0 \pm 1 \cdot 3$ & $399 \cdot 8 \pm 4 \cdot \cdot 1$ & $1 \cdot 8 \pm 0 \cdot 1$ & $6 \cdot 6 \pm 0 \cdot 7$ & $2 \cdot 6 \pm 0 \cdot 5$ \\
8 & 4 & $1921 \pm 199$ & $9 \cdot 6 \pm 0 \cdot 6$ & $374 \cdot 4 \pm 48 \cdot 2$ & $1 \cdot 6 \pm 0 \cdot 1$ & $8 \cdot 1 \pm 1 \cdot 3$ & $2 \cdot 4 \pm 0 \cdot 1$ \\
24 & 4 & $1308 \pm 23$ & $4 \cdot 2 \pm 0 \cdot 1$ & $309 \cdot 8 \pm 12 \cdot 2$ & $1 \cdot 4 \pm 0 \cdot 1$ & $22 \cdot 4 \pm 4 \cdot 3$ & $2 \cdot 4 \pm 0 \cdot 2$ \\
\hline
\end{tabular}

* Mean number of $\mathrm{ct} / \mathrm{min} / \mathrm{ml} \pm$ S.E.

$\dagger$ Mean number of $\mathrm{ct} / \mathrm{min} / \mathrm{mg}$ wet weight \pm S.E.

$24 \mathrm{hr}$. As shown in Table 1, $\left[{ }^{3} \mathrm{H}\right]$ AMD entered the circulatory system (blood plasma) from the left testis, but the plasma concentration of label continually decreased. The liver took up labelled antibiotic from the blood plasma, but it did not show a net accumulation of AMD (Table 1).

Stages of spermatogenesis in rodents have been defined by spermatid acrosomal development during spermiogenesis according to LeBlond \& Clermont $(1952 \mathrm{a}, \mathrm{b})$. Fourteen stages of spermatogenesis in the Chinese hamster have been described in our laboratory using the PAS method of LeBlond \& Clermont (Marshall \& Brinkley, 1972). The autoradiographic results which we report here utilized these spermatogenic stages as points of reference.

Plate 1, Fig. 1 is an autoradiograph of a Stage $\mathrm{V}$ seminiferous tubule from a control testis. Lack of specific labelling indicates the absence of $\left[{ }^{3} \mathrm{H}\right] \mathrm{AMD}$. Plate 1, Fig. 2 is an autoradiograph of a Stage $\mathrm{V}$ tubule from the experimental testis of the same animal. Pachytene nuclei possess a few scattered grains, and round spermatid nuclei are lightly labelled. The grain density over elongated spermatids (Step 17) is so high that exact outlines of spermatid heads are obscured. Equivalent high grain densities as represented by Step 17 spermatids (PI. 1, Fig. 2) were found over Step 15 to 18 elongated spermatids which are present in Stages I to VII of Chinese hamster spermatogenesis. Such labelled tubules are found in abundance in testicular cross-sections and for at least $250 \mu \mathrm{m}$ on either side of the mid-cross-sectional place of the testis (plane along which testes were bisected before fixation). 
An autoradiograph of a control Stage VIII seminiferous tubule is shown in Pl. 1, Fig. 3. This autoradiograph indicates the absence of $\left[{ }^{3} \mathrm{H}\right] \mathrm{AMD}$ in the spermatogenic cells of this tubule. In the treated testis from the same animal, Stage VIII leptotene nuclei appear heavily grained (Pl. 1, Fig. 4). Pachytene cells of this tubule are necrotic as shown by their contracted, heavily-stained cytoplasm. Few grains could be found over these damaged pachytene nuclei or Step 8 round spermatid nuclei. Step 19 elongated spermatids (spermiation step), which are present but not shown in Pl. 1, Fig. 4, were also labelled but not as much as Step 17 elongated spermatids (Pl. 1, Fig. 2). The tissue in Pl. 1, Fig. 4 shows the typical damage caused by AMD and the $\left[{ }^{3} \mathrm{H}\right] \mathrm{AMD}$ binding in Stage VIII tubules.

Table 2. Differential binding of $\left[{ }^{3} \mathrm{H}\right]$ actinomycin $\mathrm{D}$ to Chinese hamster spermatocytes and spermatids

\begin{tabular}{l|c|c}
\hline \multirow{1}{*}{\multicolumn{1}{c|}{ Cell type }} & \multicolumn{2}{|c}{ No. of grains/nucleus $($ Mean \pm S.E.) } \\
\cline { 2 - 3 } & Control & AMD* \\
\hline Stage VIII leptotene & $0 \cdot 9 \pm 0 \cdot 10(95)$ & $31 \cdot 6 \pm 0 \cdot 76(110)$ \\
Stage V pachytene & $0 \cdot 5 \pm 0.05(179)$ & $6 \cdot 2 \pm 0.25(155)$ \\
Step 5 round spermatid & $0 \cdot 6 \pm 0.06(424)$ & $3 \cdot 6 \pm 0 \cdot 15(171)$ \\
Step 8 round spermatid & $0 \cdot 6 \pm 0 \cdot 05(313)$ & $3 \cdot 8 \pm 0 \cdot 10(213)$ \\
\hline
\end{tabular}

Values in parentheses indicate sample size.

* Actinomycin D values not corrected for background.

Plate 1, Fig. 5 is an autoradiograph of two adjacent seminiferous tubules from a treated testis. Stage VIII leptotene nuclei show their typical labelling with $\left[{ }^{3} \mathrm{H}\right] \mathrm{AMD}$. By contrast, in the adjacent tubule, few grains are present over Stage V pachytene nuclei and Step 5 round spermatid nuclei, whereas elongated Step 17 spermatids are heavily labelled. Both tubules were exposed to $\left[{ }^{3} \mathrm{H}\right] \mathrm{AMD}$ as shown by the presence of labelled cells in each.

Grain counts over the nuclei of Stage V and VIII seminiferous tubules were made in order to compare different spermatogenic cells with regard to their

\section{EXPLANATION OF PLATE 1}

Autoradiographs of seminiferous tubules from Chinese hamsters that received intratesticular injections of either Hanks' salt solution or $\left[{ }^{3} \mathrm{H}\right]$ actinomycin $\mathrm{D}$.

Fig. 1. A Stage V seminiferous tubule from a testis injected with Hanks' salt solution. Note the lack of specific labelling. Elongated spermatids (ES), round spermatids (RS) and pachytene nuclei $(\mathrm{P}) . \quad \times 1235$.

FIG. 2. A Stage $V$ seminiferous tubule from a testis injected with $2.0 \mu \mathrm{g}\left[{ }^{3} \mathrm{H}\right]$ actinomycin $\mathrm{D}$ for $24 \mathrm{hr}$. Note the heavy specific labelling over elongated spermatids (ES). Round spermatids (RS) and pachytene nuclei (P). $\quad \times 1235$.

Fig. 3. A Stage VIII seminiferous tubule from a testis injected with Hanks' salt solution. Note the absence of grains over spermatogenic cells. Leptotene nuclei $(L)$, pachytene nuclei $(P)$ and round spermatids $(\mathbf{R S}) . \quad \times 1235$.

Fig. 4. A Stage VIII seminiferous tubule from a testis injected with $2.0 \mu \mathrm{g}\left[{ }^{3} \mathrm{H}\right]$ actinomycin $\mathrm{D}$ for $24 \mathrm{hr}$. Note the specific labelling of leptotene nuclei $(\mathrm{L})$ and the presence of necrotic pachytene cells (NP). Round spermatids (RS). $\quad \times 1235$.

FIG. 5. Two adjacent seminiferous tubules from a testis injected with $2.0 \mu \mathrm{g}\left[{ }^{3} \mathrm{H}\right]$ actinomycin D. Tubule A is in Stage VIII, and tubule B is in Stage V. The inset is of elongated spermatids present in tubule $B$. Leptotene nuclei $(L)$, pachytene nuclei $(P)$ and round spermatids $(\mathbf{R S}) . \quad \times 1235$. 
PLATE 1
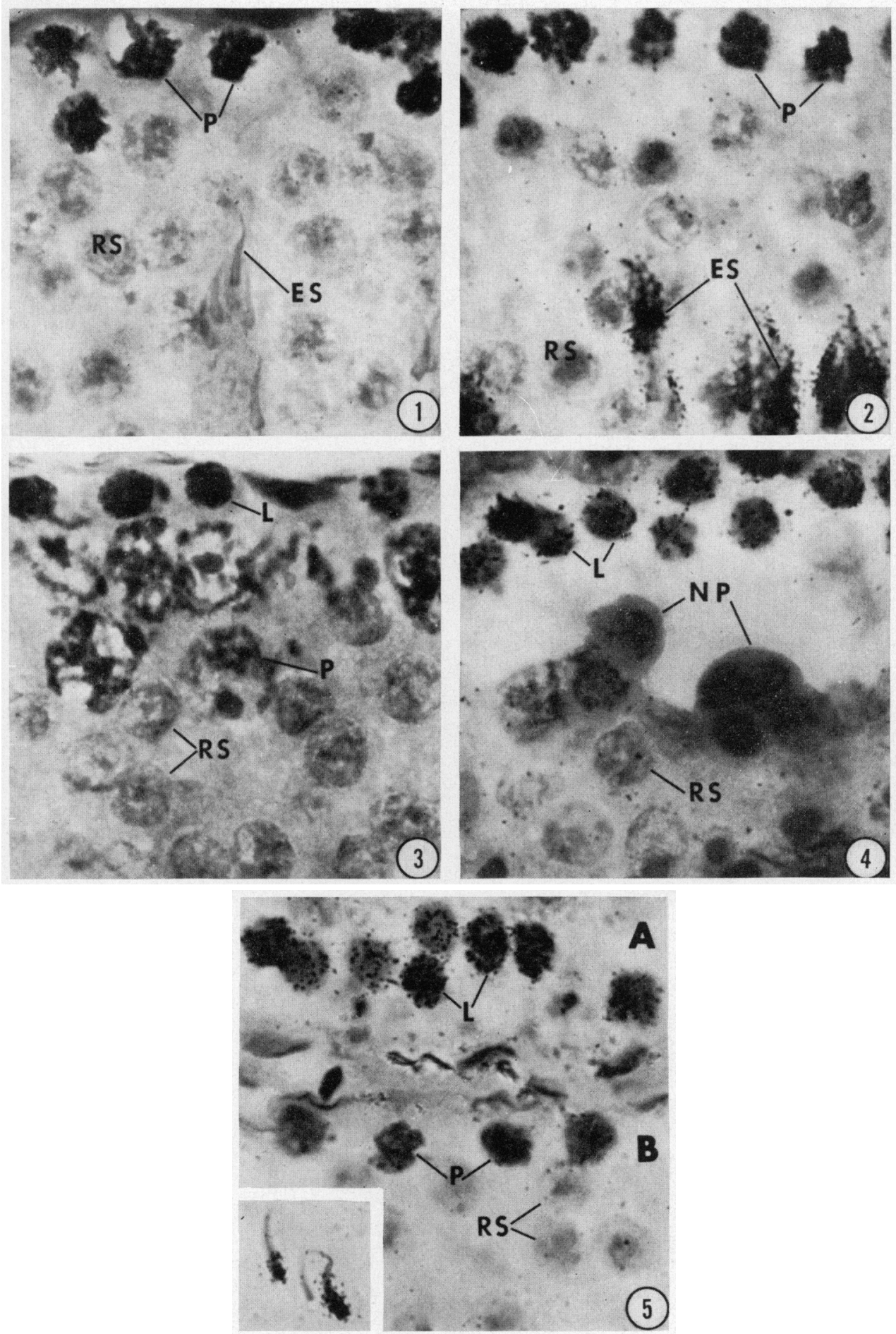

(Facing p. 44) 
binding of labelled antibiotic. Only those cells which had spherical nuclei of nearly the same diameter, and which appeared to be sectioned through their centres were scored. As can be seen from Table 2, labelling of all treated cells was higher than the background of their corresponding controls. This table also shows that nuclei of Stage VIII leptotene and Stage V pachytene cells were more significantly labelled than were either Step 5 or Step 8 round spermatid nuclei.

During spermiogenesis, round spermatid nuclei undergo an elongation process. Variations in labelling intensities occurred during this process. Round spermatids (Steps 1 to 8) and elongating spermatids (Steps 9 to 14) in the Chinese hamster were only slightly labelled with $\left[{ }^{3} \mathrm{H}\right]$ AMD. Fully elongated spermatids (Steps 15 to 18) were so heavily labelled (Pl. 1, Figs 2 and 5) that they could not be quantified in the present experiments. Labelling decreased in Step 19 spermatids as previously mentioned.

\section{DISCUSSION}

Barcellona \& Brinkley (1973) showed that when AMD was injected into one testis of a Chinese hamster, RNA synthesis in leptotene and pachytene nuclei was substantially inhibited, some pachytene cells became necrotic and the specific AMD-induced lesion, nucleolar segregation, occurred in different cell types of that testis. In the contralateral control testis injected with HSS, none of the above-mentioned effects was ever observed. One objective of the present study was to determine the distribution of $\left[{ }^{3} \mathrm{H}\right]$ AMD in different body compartments, particularly the reproductive organs, after direct injection of labelled antibiotic into one testis. Our results demonstrate that slightly more than $50 \%$ of the AMD injected into the left testis gained access to the circulatory system for general body distribution over a 24-hr period. Label was removed from the circulation at a greater rate than that at which it entered from the left testis as indicated by the continual decrease in the radioactivity of the blood plasma during the experimental period. It has been demonstrated that AMD is rapidly cleared from the circulation of rats when it is given by intracardiac (Wosilait \& Eisenbrandt, 1971) or intravenous (Schwartz, Sternberg \& Philips, 1968) routes. The antibiotic has been shown to appear in liver bile within minutes after injection (Wosilait \& Eisenbrandt, 1971). After $24 \mathrm{hr}$, it is found in urine, and more particularly in bile and faeces (Schwartz et al., 1968). In the present study, we injected animals with a small total dosage $(2.0 \mu \mathrm{g})$ of antibiotic, and $\left[{ }^{3} \mathrm{H}\right] \mathrm{AMD}$ did not show a net accumulation in the liver. This may reflect the rapid clearance of relatively low levels of AMD from the blood plasma into urine and bile.

Ro \& Busch (1965) administered $\left[{ }^{14} \mathrm{C}\right] \mathrm{AMD}$ intravenously to rats; the greatest amounts of radioisotope were found in kidney, liver and spleen after a 15-min period, whereas testis and brain contained exceedingly small amounts of radioactivity. Although not directly comparable to the data of Ro \& Busch because of the different modes of administration and different isotopic concentrations utilized, the apparent lack of uptake of radioactive AMD from the blood plasma into control testes in our experiments agrees with their results. 
The presence of a blood-testis barrier in pubertal and adult rats was suggested because of lack of testicular staining after intravenous, intraperitoneal or subcutaneous injections with various vital dyes (Kormano, 1967). The ultrastructural feature for the blood-testis barrier has been elucidated in the guinea-pig (Fawcett, Leak \& Heidger, 1970) and rat (Dym \& Fawcett, 1970). In rodents, this barrier appears to be related to the cellular junctions which occur between peritubular myoid cells and between adjacent Sertoli-cell membranes within seminiferous tubules. It is probable that some seminiferous tubules may be damaged by intratesticular injections. If this is the case, then injected substances may be able to circumvent the blood-testis barrier by gaining access to seminiferous tubules from the luminal surface of the seminiferous epithelium. The significant confinement of radioisotope to the treated testis and the lack of uptake of $\left[{ }^{3} \mathrm{H}\right] \mathrm{AMD}$ from the blood plasma by the control testis in our experiments might be attributed to the effectiveness of the blood-testis barrier.

Kormano (1967) has shown that the caput epididymidis in the adult rat is permeable to vital dyes while other portions of the epididymis are not. The $\left[{ }^{3} \mathrm{H}\right]$ AMD content of entire epididymides was measured in the present study. Left epididymides gradually accumulated $\left[{ }^{3} \mathrm{H}\right] \mathrm{AMD}$ over $24 \mathrm{hr}$, but right epididymides did not. Although it is possible that the caput epididymides might have taken up small amounts of label from blood plasma, our results suggest that the left epididymis accumulated labelled antibiotic mainly by intratubular transport from the left testis under the conditions of the present experiments.

The second aspect of the present work localizes and estimates the extent of differential binding of $\left[{ }^{3} \mathrm{H}\right] \mathrm{AMD}$ in vivo to some spermatogenic cells of the Chinese hamster. Actinomycin D has been shown to bind selectively with different types of somatic cells (Bolund, 1970), with different cells from the same population (Bolund, 1970; Ringertz, Darżynkiewicz \& Bolund, 1969), with synchronously dividing tissue culture cells during the cell cycle (Pederson \& Robbins, 1972) and with different types of spermatogenic cells in the mouse (Brachet \& Hulin, 1969), ram (Loir \& Hochereau-de Reviers, 1972) and bull (Darżynkiewicz et al., 1969; Loir \& Hochereau-de Reviers, 1972). All of the studies on spermatogenic cells have employed quantitative autoradiography of whole-cell preparations that were incubated with $\left[{ }^{3} \mathrm{H}\right] \mathrm{AMD}$ in vitro. The selective AMD-binding found in our study on Chinese hamster seminiferous epithelium might be explained by three factors: permeability differences between seminiferous tubules, permeability differences between spermatogenic cell-types or differential affinities of chromatin in spermatogenic cells for binding with AMD. Tubular permeability is probably of no great significance when the antibiotic is administered intratesticularly since our results show there is consistent, widespread labelling of the seminiferous tubules. This would indicate that the radioisotope probably bypassed the blood-testis barrier and was adequately distributed in the seminiferous epithelium by entering some seminiferous tubules which were damaged by the intratesticular injection. Cellular permeability might influence differential binding; however, studies on fresh and aged bull spermatozoa in vitro (Gledhill, Darżynkiewicz \& Ringertz, 1971) and on HeLa cells and lymphocytes (Bolund, 1970) demonstrate that penetration of the cell membrane by AMD is not a significant factor affecting its 
binding to chromatin material. Variations among individual cell types is apparently the most probable explanation for differential binding of AMD in vivo by Chinese hamster seminiferous epithelium. Brachet \& Hulin (1969) have shown that mouse spermatocytes bind more AMD than spermatids or spermatozoa, but neither specific types of spermatocytes nor specific spermatid steps were identified. Loir \& Hochereau-de Reviers (1972) found that pachytene spermatocytes were more heavily labelled with AMD than were round spermatids in the bull. We have demonstrated that leptotene and pachytene spermatocytes bound more AMD than corresponding round spermatids in the same respective seminiferous tubules from Chinese hamsters (Table 2 and $\mathrm{Pl}$. 1, Figs 2 and 4). Our results, which indicate that AMD-binding decreases as cells progress in their development from primary spermatocytes to round spermatids, are in agreement with the data of Brachet \& Hulin (1969) and Loir \& Hochereau-de Reviers (1972). Since relatively large amounts of RNA are synthesized in Chinese hamster leptotene and pachytene nuclei (Utakoji, 1966), and treatment with AMD inhibits this RNA synthesis (Barcellona \& Brinkley, 1973), it is possible that the physicochemical status of chromatin material in these cells influences their AMD-binding capacities.

Loir \& Hochereau-de Reviers (1972) have reported the occurrence of differential AMD-binding during spermiogenesis in the ram and bull. The present work has shown a similar pattern in Chinese hamster spermiogenesis. Round and elongating spermatids were lightly labelled, while elongated spermatids possessed a very high label intensity with the exception of the final spermatid step. One explanation might be that as spermatid nuclei elongate and their chromatin material condenses, the condensation process favours the closer proximity of bound AMD molecules to one another with a concomitant increase in grain density in autoradiographs. This possibility can probably be eliminated since our experiments were of relatively short duration in comparison to the time required for spermatid maturation. It has been demonstrated that deoxyribonucleoprotein complexes are physically and chemically altered in metamorphosing bull spermatids (Gledhill, Gledhill, Rigler \& Ringertz, 1966; Ringertz, Gledhill \& Darżynkiewicz, 1970). Furthermore, Loir \& Hochereaude Reviers (1972) have reported that there is a shift from lysine-rich histones to arginine-rich histones in developing ram spermatids; these protein alterations are accompanied by changes in content of free phosphoryl groups of nucleic acids which, in turn, directly parallel differential AMD-binding to spermatid nuclei. Loir \& Hochereau-de Reviers (1972) have suggested that during specific phases of spermiogenesis, sites on nuclear chromatin become available for binding with AMD due to physicochemical alterations of spermatid deoxyribonucleoprotein complexes. This phenomenon may result in the selective AMDbinding which is characteristic of the different spermatid steps.

In summary, when $\left[{ }^{3} \mathrm{H}\right] \mathrm{AMD}$ is injected into one testis of a Chinese hamster, approximately $50 \%$ of the dose enters the circulatory system and small amounts of antibiotic are transported to the ipsilateral epididymis after $24 \mathrm{hr}$. The remaining AMD is retained in the testis into which it was injected. Neither the contralateral control testis nor the contralateral control epididymis take up significant levels of antibiotic from the blood supply. In the testis treated 
with AMD, the antibiotic binds selectively with spermatocytes and spermatids in particular. This differential binding may be a consequence of the physicochemical state of deoxyribonucleoprotein complexes existing in spermatocytes, and round, elongating and elongated spermatids.

\section{ACKNOWLEDGMENT}

This study was supported by Contract No. 69-2139 from the Contraceptive Development Branch of the National Institute of Child Health and Human Development.

\section{REFERENGES}

Barcellona, W. J. \& Brinkley, B. R. (1973) Effects of actinomycin D on spermatogenesis in the Chinese hamster. Biol. Reprod. 8, 335.

Baserga, R. \& Malamud, D. (1969) Autoradiography. In Modern Methods in Experimental Pathology, p. 22. Harper and Row, New York.

Botund, L. (1970) Actinomycin D binding to isolated deoxyribonucleoprotein and intact cells. Expl Cell Res. 63, 171.

Brachet, J. \& Hulin, N. (1969) Binding of tritiated actinomycin and cell differentiation. Nature, Lond. 222, 481.

Darżynkiewicz, Z., Gledhill, B. L. \& Ringertz, N. R. (1969) Changes in deoxyribonucleoprotein during spermiogenesis in the bull. $\left[{ }^{3} \mathrm{H}\right]$ actinomycin D binding capacity. Expl Cell Res. 58, 435.

DYM, M.\& FAWCETT, D. W. (1970) The blood-testis barrier in the rat and the physiological compartmentation of the seminiferous epithelium. Biol. Reprod. 3, 308.

Fawcett, D. W., Leak, L. V. \& Herdger, P. M., JR (1970) Electron microscopic observations on the structural components of the blood-testis barrier. 7. Reprod. Fert., Suppl. 10, 105.

Gledhill, B. L., Darżynkiewicz, A. \& Ringertz, N. R. (1971) Changes in deoxyriboneucloprotein during spermiogenesis in the bull: increased $\left[{ }^{3} \mathrm{H}\right]$ actinomycin $D$ binding to nuclear chromatin of morphologically abnormal spermatozoa. F. Reprod. Fert. 26, 25.

Gledhill, B. L., Gledhill, M. P., Rigler, R., JR \& Ringertz, N. R. (1966) Changes in deoxyribonucleoprotein during spermiogenesis in the bull. Expl Cell Res. 41, 652.

Kormano, M. (1967) Dye permeability and alkaline phosphatase activity of testicular capillaries in the postnatal rat. Histochemie, 9, 327.

LeBlond, G. P. \& Clermont, Y. (1952a) Spermiogenesis of rat, mouse, hamster and guinea-pig as revealed by the 'periodic acid-fuchsin sulfurous acid' technique. Am. F. Anat. 90, 167.

LeBlond, C. P. \& Clermont, Y. (1952b) Definition of the stages of the cycle of the seminiferous epithelium in the rat. Ann. N.Y. Acad. Sci. 55, 548.

LoIR, M. \& Hochereau-De Reviers, M. T. (1972) Deoxyribonucleoprotein changes in ram and bull spermatids. F. Reprod. Fert. 31, 127.

Marshald, G. \& Brinke.ey, B. R. (1972) Dynamics of seminiferous epithelium in mammals by ultrastructural analysis. Tex. Rep. Biol. Med. 30, 385.

Monest, V. (1964) Ribonucleic acid synthesis during mitosis and meiosis in the mouse testis. f. Cell Biol. 22, 521.

Monesi, V. (1965) Differential rate of ribonucleic acid synthesis in the autosomes and sex chromosomes during male meiosis in the mouse. Chromosoma, 17, 11.

Pederson, T. \& Robins, E. (1972) Chromatin structure and the cell division cycle. Actinomycin binding in synchronized HeLa cells. F. Cell Biol. 55, 322.

Ringertz, N. R., Darżynkiewicz, Z. \& Bolund, L. (1969) Actinomycin D binding properties of stimulated human lymphocytes. Expl Cell Res. 56, 411.

Ringertz, N. R., Gledhill, B. L. \& Darżynkiewicz, Z. (1970) Changes in deoxyribonucleoprotein during spermiogenesis in the bull. Sensitivity of DNA to heat denaturation. Expl Cell Res. 62, 204.

Ro, T. S. \& Busch, H. (1965) Concentration of $\left[{ }^{14} \mathrm{C}\right]$ actinomycin $\mathrm{D}$ in various tissues following intravenous injection. Biochim. biophys. Acta, 108, 317.

Schwartz, H. S., Sternberg, S. S. \& Philips, F. S. (1968) Selective cytotoxicity of actinomycin in mammals. In Actinomycin, p. 101. Ed. S. A. Waksman. Interscience, New York.

Wosilait, W. D. \& Eisenbrand, L. L. (1971) Biliary excretion of $\left[{ }^{3} \mathrm{H}\right]$ actinomycin D in the rat. Life Sci. 10, 1051 .

Utakojr, T. (1966) Chronology of nucleic acid synthesis in meiosis of the male Chinese hamster. Expl Cell Res. 42, 585. 